JIIP: Jurnal IImiah IImu Pemerintahan

Volume 5, Nomor 2, Tahun 2020

DOI: $10.14710 / j i i p . v 5 i 2.7690$

\title{
Gratifikasi di Badan Usaha Milik Negara Berdasarkan Motif Kecurangan: Sebuah Tinjauan Literatur
}

\author{
Irvan Sebastian Iskandar ${ }^{1}$, Teguh Kurniawan ${ }^{2}$ \\ ${ }^{1,2}$ Magister Ilmu Administrasi, Fakultas IImu Administrasi, Universitas Indonesia
}

\begin{abstract}
INTISARI
Menurut laporan Komisi Pemberantasan Korupsi (KPK) dari tahun 2015 sampai 2019, jumlah laporan gratifikasi pada Badan Usaha Milik Negara di Indonesia menempati urutan kedua terbanyak setelah lembaga eksekutif. Kasus gratifikasi merupakan tindakan kecurangan yang sebenarnya bisa menjerat pelaku sebagai bentuk tindakan korupsi. Perbuatan gratifikasi tidak boleh lagi dianggap remeh layaknya perbuatan korupsi lainnya. Untuk itu, butuh penjelasan yang mendalam guna menguraikan terjadinya tindakan ini. Dengan metode kualitatif yang dipadukan dengan penggunaan faktor-faktor penyebab pada teori motif kecurangan, tulisan ini mencoba menjelaskan mengapa gratifikasi terjadi. Sayangnya, meski dilarang dan ada ancaman hukuman pidana korupsi, praktik ini masih kerap diterima dan terjadi oleh para penyelenggara negara yang ada di BUMN. Hasilnya, ada beberapa faktor yang dominan yang menyebabkan terjadinya praktik ini, diantaranya faktor tekanan, kesempatan, rasionalisasi, dan kapabilitas yang menjadi sebab bagi seorang penyelenggara negara melakukan perbuatan kecurangan tersebut.
\end{abstract}

KATA KUNCl

BUMN; gratifikasi; kecurangan; korupsi; teori motif

\section{Pendahuluan}

osisi badan usaha milik negara (BUMN) memiliki tiga konfigurasi kepentingan dan pengaruh, bukan hanya pemerintah saja, tetapi sekaligus pasar dan juga publik (Anita, 2017; Yeung, 2005). Tidak terkecuali bagi BUMN di Indonesia yang berbisnis sekaligus mendapat tugas kewajiban pelayanan publik sesuai dengan undang-undang. Menuntut organisasi ini harus bisa dikelola secara profesional. Sebagaimana pentingnya mereka mengambil peran menjadi salah satu bagian sejarah suatu negara dalam bentuk kemandirian ekonomi dan identitas politik nasional, membangun kekuatan pertahanan negara, dan penciptaan re-distribusi sosial dari modal yang

\section{Korespodensi:}

Magister Ilmu Administrasi, Universitas Indonesia, Gedung M Lantai 2, Komplek FISIP, JI. Prof. DR. Selo Soemardjan, Pondok Cina, Kecamatan Beji, Kota Depok, Jawa Barat 1642.

Email: sebastian.irvan@gmail.com 
Irvan S. Iskandar \& Teguh Kurniawan | Gratifikasi di Badan Usaha Milik Negara Berdasarkan Motif...

dikumpulkan kembali yang berpangkal untuk kesejahteraan warga negaranya (Huat, 2016; Kankaanpää, Oulasvirta, \& Wacker, 2014; Putniņš, 2015).

Ketika BUMN di Indonesia semakin besar porsi perannya dalam perekonomian negara, dan sekaligus mendapatkan tugas kewajiban pelayanan publik sesuai amanah undang-undang. Dalam praktik berbisnisnya, tidak jarang mereka (pegawai dan pimpinan) menghadapi aktivitas dilematis berupa menerima sebuah gratifikasi yang biasanya lazim diterima dalam kegiatan bisnis. Padahal pegawai dan pimpinan perusahaan negara, dalam posisinya adalah termasuk sebagai salah satu penyelenggara negara. Mereka bekerja berkaitan dan dekat dengan fasilitas beserta uang dari negara di dalamnya. Sementara, apabila ongkos gratifikasi oleh seorang pemberi dimasukkan sebagai biaya atau variabel tambahan dalam sebuah produknya. Dikhawatirkan akan berpotensi menimbulkan kerugian negara karena harga barang/jasa yang dibeli dengan menggunakan uang publik bisa menjadi lebih mahal, atau yang lebih parah, terjadinya sebuah keputusan yang tidak objektif karena timbul sebuah konflik kepentingan atau terpengaruh karena terjadinya suap.

Bentuk gratifikasi memang sama seperti suap, tetapi tidak memerlukan beban pembuktian atau berupa niat intens yang bertujuan untuk mempengaruhi sebuah keputusan Association of Certified Fraud Examiners (Manual, 2011). Apabila diilustrasikan dalam sebuah pohon kecurangan (fraud tree), gratifikasi merupakan salah satu perilaku dari rantingnya sebuah tindakan kecurangan. Lebih tepat dan spesifiknya merupakan cabang yang masuk dalam kategori sebagai tindakan korupsi, dan bisa menjerat seorang pelaku ke dalam pasal tindak pidana korupsi. Dalam proses peradilan pidana korupsi, jika beberapa kriteria dan kondisi tertentu bisa terpenuhi serta terbukti. Gratifikasi-pun dapat berubah dianggap menjadi sebuah suap (Pasal 12B UU No. 20/2000 jo. UU No. 31/1999).

Gratifikasi menurut pandangan Santoso (2011) adalah: (1) Sebagai upaya menanam jasa kepada seseorang dengan jabatan dan pengaruh; (2) Merupakan bentuk pemberian yang bisa diberikan kapan saja tanpa ada syarat atau janji terlebih dahulu sebagai komitmen; (3) Bisa diberikan kapan saja, pada saat sedang berlangsung maupun telah selesai mendapatkan pelayanan atau keuntungan; (4) Pemberian bisa dilakukan tanpa pamrih (gratifikasi positif) maupun dengan pamrih (gratifikasi negatif). Empat poin tersebut memang menjadi dilema tersediri bagi penerimanya, tetapi apabila tindakan tersebut jika tidak diberikan batas, dikelola, dan ditindak. Dikhawatirkan amat berisiko mengarahkan kepada tindakan kecurangan yang lebih destruktif lainnya karena berupaya menanam jasa dan pengaruh pada waktu kapan-pun. Sehingga menurut Association of Certified Fraud Examiners Manual (2011) tindakan koruptif ini memiliki sebutan sebagai "Illegal Gratuities."

Hasil laporan pada tabel di bawah menunjukkan, perusahaan milik negara seperti BUMN dan BUMD (badan usaha milik daerah) menempati urutan terbanyak kedua dalam 
perihal laporan gratifikasinya. Jumlahnya mengalahkan laporan dari instansi tinggi negara bidang legislatif dan yudikatif. Bisa dibayangkan dari banyaknya laporan gratifikasi yang diterima oleh BUMN/BUMD tersebut. Jika tidak adanya kesepahaman, keseriusan, tidak berjalan pengelolaan atau tidak dilaporkan untuk menggugurkan sanksi hukumnya sesuai peraturan UU Tindak Pidana Korupsi. Pasti akan ada banyak para pegawai dan pimpinan bisnis milik negara yang akan terjerat dalam kasus pidana korupsi pada sektor bisnis akibat sebuah pemberian ilegal ini. Terkumpul sejumlah laporan gratifikasi dari Komisi Pemberantasan Korupsi, sebagai berikut.

Tabel 1. Jumlah Laporan Gratifikasi Berdasarkan Instansi

\begin{tabular}{|l|l|l|l|l|l|l|}
\hline \multirow{2}{*}{ No. } & \multirow{2}{*}{ Instansi } & \multicolumn{5}{|c|}{ Jumlah Laporan Gratifikasi } \\
& & 2015 & 2016 & 2017 & 2018 & 2019 \\
\hline 1 & Eksekutif * & 658 & 1.136 & 789 & 1.476 & 1.806 \\
\hline 2 & Badan Usaha Milik Negara/Daerah & 805 & 731 & 772 & 717 & 598 \\
\hline 3 & Legislatif (MPR/DPR, DPD \& DPRD) & 25 & 20 & 15 & 35 & 8 \\
\hline 4 & Yudikatif & 16 & 7 & 259 & 11 & 16 \\
\hline 5 & Lembaga Independen & 69 & 54 & 9 & 108 & 92 \\
\hline 6 & Swasta/privat & - & - & 1 & 2 & 3 \\
\hline Total penerimaan & 1.573 & 1.948 & 1.845 & 2.349 & 2.523 \\
\hline
\end{tabular}

Sumber: Laporan Tahunan Komisi Pemberantasan Korupsi, diolah penulis.

Keterangan: *Termasuk Kepresidenan, Kementerian Negara, LPNK, Lembaga ekstra struktural, Lembaga setingkat kementerian, Pemerintah daerah.

Salah satu contoh kasus gratifikasi yang terseret ke ranah pidana karena tidak dilaporkan dan akhirnya berhasil di usut. Adalah kasus gratifikasi BUMN PT Garuda Indonesia (Persero) Tbk. Pelaku yang merupakan salah satu mantan direktur perusahaan yang mendapatkan jerat dakwaan pasal gratifikasi, kemudian berkembang menjadi dakwaan suap dan pencucian uang dengan melibatkan perusahaan multinasional dan kawan dekatnya sebagai perantara dalam proyek pengadaan barang perusahaan (Kompas.com, 2020).

Sejalan juga dengan fakta yang ditemukan kalau suap, yang dimungkinkan berawal mula dari mewajarkan sebuah gratifikasi, merupakan kasus korupsi yang kini paling banyak diusut oleh Komisi Pemberantasan Korupsi (2018). Mereka yang terlibat dan menjadi terdakwa adalah seseorang dengan pengaruh, baik di sektor publik maupun sektor bisnis seperti BUMN. Kasus tersebut jelas mencoreng nama baik kredibilitas dan etika sebagai penyelenggara negara, apalagi pada sebuah perusahaan negara. Perbuatan yang dilakukan oleh terdakwa (menerima gratifikasi atau korupsi), ternyata bisa juga terjadi pada sebuah 
Irvan S. Iskandar \& Teguh Kurniawan | Gratifikasi di Badan Usaha Milik Negara Berdasarkan Motif...

perusahaan milik negara dan menjadi sebuah keperluan untuk segera direformasi (Zhao \& Zhang, 2015).

Berangkat dari banyaknya kasus suap dan berdasarkan adanya rekapitulasi laporan penerimaan gratifikasi dari BUMN di Indonesia. Menjadi sebuah keperluan untuk menguraikannya lebih lanjut. Mengenai motif apa saja sebagai alasan yang melatarbelakangi sebuah gratifikasi menjadi lazim terjadi serta masih diterima oleh para penyelenggara negara yang ada di BUMN, dan mengapa menjadi sebuah keharusan bagi instansinya agar ikut melakukan pelaporan atas gratifikasi tersebut. Sebagai instansi milik negara dengan kegiatan bisnis yang kini dituntut kesadaran, kepatuhan dan keikutsertaannya untuk mengatasi tindakan korupsi yang dilematis seperti gratifikasi.

Dengan menggunakan pendekatan kualitatif. Pengumpulan data, konsep-konsep dan teori yang digunakan dalam artikel ini dilakukan melalui kajian kepustakaan berupa literatur yang berasal dari buku, jurnal penelitian dan dokumen laporan yang berkaitan dengan topik penelitian (Creswell, 2014). Mengacu pada Gabrielian, Yang \& Spice (2018) penulis melakukan analisis data ke dalam tiga proses aktivitas besar, yaitu; (1) Mereduksi data untuk diseleksi agar terpilih informasi dan data yang relevan untuk disajikan; (2) Menampilkan dan menyajikan data; dan terakhir (3) Menarik kesimpulan. Aktivitas tersebut dilakukan untuk mengetahui situasi yang kini juga dihadapi oleh instansi di luar lingkup tiga instansi tinggi negara (eksekutif, legislatif, dan yudikatif).

\section{Gratifikasi, Korupsi dan Motif Kecurangan}

Association of Certified Fraud Examiners dalam pandangan Manual (2011) membagi sebuah kecurangan ke dalam tiga kelompok tindakan besar. Tindakan itu berupa korupsi, penggelapan aset, dan rekayasa laporan keuangan. Gratifikasi atau illegal gratuities sebagai pembahasan pada artikel ini, merupakan salah satu perbuatan yang berada pada rumpun korupsi bersamaan dengan suap, konflik kepentingan, dan pemerasan. Korupsi sendiri merupakan tindakan yang berkaitan sebagai aktivitas memberi/menerima agar seseorang mau atau tidak mau melakukan sesuatu, melanggar aturan formal, menguntungkan diri sendiri atau kelompoknya, dan dilakukan secara rahasia (Argandona, 2005).

Perbuatan gratifikasi terkadang bermakna sebagai sebuah pemberian yang bersifat sosial dan wajar dalam bermasyarakat. Tetapi pada perkembangannya berubah menjadi dilematis dan berbahaya manakala pemberian tersebut bertujuan mengincar ingatan baik sebagai tabungan jasa di masa depan kepada seseorang. Apalagi kepada mereka yang berpengaruh dan bertugas sebagai penyelenggara negara. Meski tidak ada niat secara langsung dan sifatnya yang cenderung pasif, potensi dari perbuatan ini dapat memancing kerugian yang lebih besar karena bisa mengaburkan nilai keadilan dan objektivitas seseorang penerimanya. Dalam kacamata tindakan kecurangan, setidaknya perbuatan ini 
telah mencakup beberapa elemen berupa adanya representasi materi, perbuatan yang salah, dilakukan secara sengaja, dan berpotensi menimbulkan kerusakan/kerugian (Albrecht, Albrecht, Albrecht, \& Zimbelman, 2011). Dengan begitu gratifikasi disepakati menjadi salah satu bentuk kecurangan yang berbahaya dan terlarang, bagian dari bentuk korupsi. Lebih tepatnya digunakan untuk membantu sulitnya dalam pembuktian sebuah tindakan suap (Santoso, 2011).

Bagai dua sisi mata uang koin, meski terlarang dan berbahaya, gratifikasi masih saja kerap terjadi dan bisa diterima sama halnya dengan suap. Gratifikasi bisa dipersamakan menjadi sebuah suap apabila pelaku sebagai penerima terbukti melakukan sesuatu perbuatan yang berlawan dengan tugas atau kewajibannya (Jessica, 2015). Oleh karena itu, perbuatan curang ini memerlukan penjabaran yang tepat. Soal faktor apa saja sebagai alasan atau penyebab seorang pejabat publik atau penyelenggara negara masih kerap melakukan atau menerima tindakan tersebut.

Penelitian dari Satyoadi (2015) pada lembaga eksekutif pemerintah daerah, menunjukkan kalau sistem pengendalian internal di lembaga tersebut ternyata belum terbukti efektif mencegah tindakan suap dan gratifikasi. Sistem pengendalian internal yang sudah berjalan hanya mampu mewujudkan keterandalan laporan keuangan saja. Kemudian penelitian dari Fathonah (2017) pada lembaga eksekutif kementerian menunjukkan, kalau gratifikasi sebetulnya dapat dikendalikan melalui upaya penguatan budaya kerja organisasi. Dengan tiga aspeknya yang terdiri dari tindakan pimpinan, pemeliharaan keteraturan gugus tugas, dan pengelolaan jejaring budaya. Di mana Ketiganya perlu diinternalisasikan secara serius dan didukung kuat oleh komitmen dari segala level pimpinannya. Terakhir, adalah penelitian mengenai gratifikasi dan suap dari Mapuasari \& Mahmudah (2018) bahwa hasil penelitiannya menyebutkan kalau faktor tekanan dan rasionalisasi pada motif segitiga kecurangan dan ditambah pembelajaran dari lingkungan. Memberikan pengaruh pada keputusan etis individu yang menjadi sebuah konsensus sosial terhadap penerimaan tindakan gratifikasi dan suap.

Melanjutkan apa yang dilakukan oleh Mapuasari \& Mahmudah (2018) yang berhasil menjelaskan tindakan penerimaan terhadap gratifikasi dan suap dengan mengategorikannya sebagai bentuk kecurangan (fraud). Terjadinya sebuah penerimaan terhadap gratifikasi ternyata dapat dijelaskan dengan menggunakan teori motif segitiga kecurangan (triangle fraud) dari Cressey (1950) dan penelitian lanjutan yang dilakukan dari Dellaportas (2013) menjelaskan bahwa motif segitiga kecurangan tersebut memiliki tiga faktor pendorong utama di dalamnya. Yaitu tekanan (pressure), kesempatan (opportunity), dan rasionalisasi (rationalization). Sebagai faktor-faktor yang membuat seseorang berani melawan norma dan etika yang berlaku pada organisasinya. 
Irvan S. Iskandar \& Teguh Kurniawan | Gratifikasi di Badan Usaha Milik Negara Berdasarkan Motif...

Pada perkembangannya teori motif segitiga kecurangan ini juga terus mengalami perbaikan, penajaman, dan penambahan. Berkembang menjadi sebuah teori motif berlian kecurangan (diamond fraud) (Wolfe \& Hermanson, 2004). Dalam teori tersebut, faktor kapabilitas (capability) menambahkan tiga faktor yang sudah ada lebih dulu sebelumnya pada teori motif segitiga kecurangan (tekanan, kesempatan dan rasionalisasi). Sebagai salah satu faktor yang dapat mendorong seseorang pelaku melakukan perbuatan curang. Sebagaimana faktor-faktor yang ada pada kedua teori kecurangan ini, tergambar sebagai berikut.

Gambar 1. Motif Segitiga Kecurangan (A) dan Motif Berlian Kecurangan (B)
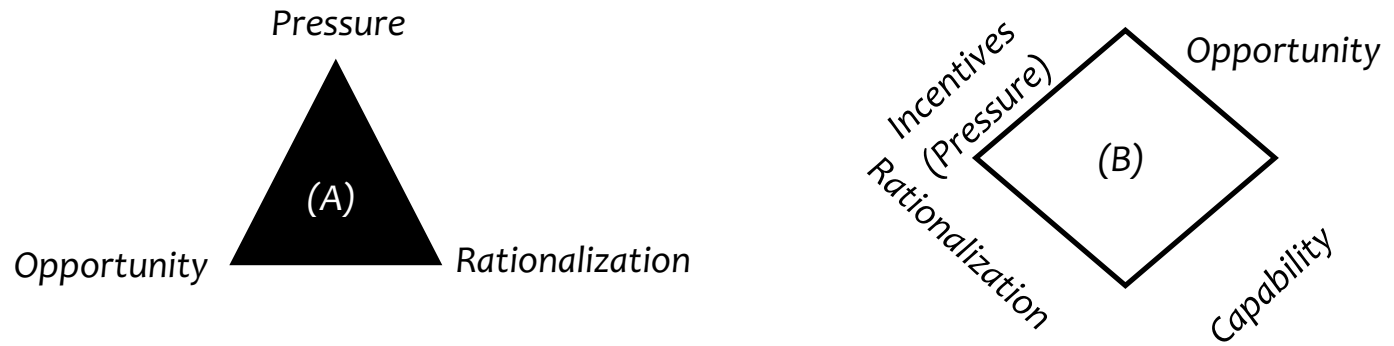

Sumber: Dellaportas, 2013; Wolfe dan Hermanson, 2004.

Dengan menggunakan faktor-faktor yang ada pada kedua motif kecurangan (Segitiga dan Berlian kecurangan), mengambil kondisi yang dihadapi, dan beberapa contoh kasus-kasus gratifikasi yang pernah menjerat di badan usaha milik negara di Indonesia. Artikel ini akan mengulasnya lebih lanjut, dalam kaitannya mengapa para penyelenggara negara masih kerap menerima tindakan gratifikasi tersebut. Menambahkan atau melengkapi penelitian yang telah lebih dulu dilakukan dan berhasil dijelaskan dengan baik oleh Mapuasari \& Mahmudah (2018) penjelasan tindakan penerimaan terhadap gratifikasi dan suap dengan mengategorikannya sebagai bentuk kecurangan (fraud).

\section{Faktor Tekanan Sebagai Pendorong Dalam Perbuatan Gratifikasi}

Faktor tekanan atau insentif, meski berbeda dalam penamaan istilah pada teori motif segitiga dan berlian kecurangan, keduanya sepakat mencantumkannya sebagai faktor konstruksi utama yang menyebabkan seseorang berkomitmen melakukan korupsi atau kecurangan. Secara lebih detail, berikut penjelasan dari Cressey (1950), Dellaportas (2013), Mapuasari \& Mahmudah (2018) mengenai apa saja bentuk dari faktor tekanan tersebut.

Pertama, adalah tekanan bersifat finansial sebagai tekanan yang berkaitan dengan kondisi keuangan atau keadaan material seseorang. Tekanan finansial merupakan nonshareable problem, masalah yang tidak bisa terbagi kepada siapa-pun atau bersifat privat, 
kecuali diri pelaku sendiri yang menyelesaikannya. Biasanya berupa sebuah tuntutan atau beban untuk memenuhi gaya hidup, membiayai kebutuhan yang mendesak atau tidak terduga (sakit atau kecelakaan), dan mungkin karena terlibat hutang yang harus segera terbayar. Pada akhirnya persoalan tersebut berubah menjadi sebuah beban bagi mereka yang mengalaminya dan tentu mempengaruhi kondisi kesehatan finansialnya. Sehingga memantik pelaku untuk tidak segan bertindak tidak etis, dengan menerima pemberian menganggapnya sebagai sebuah "rezeki tidak terduga" yang datang dari sebuah gratifikasi.

Kedua, adalah tekanan yang bersifat non-finansial. Bentuk tekanan seperti ini ternyata muncul berasal dari sifat buruk yang menyebabkan ketagihan, tekanan pekerjaan/karier, dan situasi tertentu yang sedang dihadapi seseorang ( Mansor, 2015). Dari sifat buruk yang membuat kecanduan, apalagi menyentuh sifat konsumtif misalnya. Tidak heran ada banyak bentuk gratifikasi yang diberikan dan masih diterima sebagai hal "wajar" dalam keperluan ramah-tamah melalui pemberian fasilitas berupa rabat, seks/prostitusi, judi, alkohol, dan narkoba dalam praktiknya. Sementara tekanan terkait dengan alasan pekerjaan, gratifikasi digunakan sebagai cara untuk mendapatkan atau mempertahankan sebuah jabatan atau karier sesuai dengan kepentingannya. Caranya dengan menanam jasa kepada siapa saja (umumnya atasan atau orang yang lebih berpengaruh) yang menurutnya memiliki dan memberikan potensi keuntungan di masa yang akan datang.

Bentuk tekanan lainnya menurut Kranacher dalam Dorminey, Fleming, Kranacher, \& Riley Jr (2012) yaitu Money, Ideology, Coercion dan Ego adalah empat hal lain yang melekat untuk menjelaskan faktor tekanan dalam perbuatan curang. Jika uang (money) merupakan kata lain dari tekanan finansial, maka Ideologi (ideology) memberi tekanan rasa percaya diri bagi individu untuk berpartisipasi. Sementara pemaksaan (coercion) adalah sebagai tekanan yang membuat individu ikut melakukan suatu perbuatan dengan cara ditarik paksa oleh lingkungan sekitarnya dalam lingkaran tindakan yang tidak etis. Terakhir, adalah ego sebagai tekanan akan ketakutan hilangnya reputasi individu di masyarakat jika tidak mengikuti perbuatan tersebut. Pada akhirnya membuat perilaku menerima gratifikasi menjadi sebuah hal yang lazim untuk dilakukan dalam praktiknya.

Memang cukup sulit mendeteksi dan menemukan contoh kasus gratifikasi secara langsung, khususnya dari aktivitas bisnis yang terjadi di lingkungan BUMN karena faktor tekanan. Ini karena sifatnya yang internal, menjadi rahasia yang terkesan ditutupi oleh perusahaan, dan bahkan sangat personal menyangkut pribadi masing-masing individu. Bisa juga terjadi karena dimulai dari minimnya bukti, bisa terselesaikan secara internal-personal, dan lolos dari pengawasan aparat atau eksposur media sebagai pihak eksternal instansi. Secara kesejahteraan, gaji atau penghasilan para direksi dan komisaris BUMN juga mengalami kenaikan (Hutauruk, Dina, 2018). Begitu pula penghasilan dan tunjangan karyawan BUMN yang lebih tinggi dibandingkan penghasilan para Aparatur Sipil Negara 
Irvan S. Iskandar \& Teguh Kurniawan | Gratifikasi di Badan Usaha Milik Negara Berdasarkan Motif...

(ASN) pada umumnya. Kesulitan ini sama halnya ketika hendak membuktikan gratifikasi yang berasal karena faktor tekanan non-finansial, dengan cara menerima fasilitas seks atau prostitusi, yang ternyata eksis dan terjadi, namun terjadi keterbatasan untuk membuktikannya (Tirto.id, 2019).

Tetapi pada kasus-kasus yang menyangkut seperti jual-beli, rekrutmen, dan promosi jabatan di lingkungan lembaga publik di pusat dan daerah (dinas dan badan usaha milik daerah) yang pernah ditangani Komisi Pemberantasan Korupsi bisa menjadi salah satu contohnya. Seperti kasus mantan Bupati Klaten Sri Hartini, mantan Bupati Nganjuk Taufiqurrahman, Mantan Bupati Jombang Nyono Suharli, dan Mantan Bupati Cirebon Sunjaya sebagai kasus gratifikasi yang berujung menjadi suap. Pada kasus di tingkat lembaga publik tingkat pusat, gratifikasi yang baru-baru ini terjadi yaitu di Kementerian Pemuda dan Olahraga dan Kementerian Agama (Kumparan.com, 2019). Tekanan yang dialami oleh pelaku umumnya datang karena adanya kebutuhan untuk membiayai gaya hidup yang naik karena telah menjadi pejabat, adanya pemenuhan kebutuhan finansial untuk pemilu yang mahal/mengembalikan ongkos politik yang dikeluarkan, dan membayar hutang budi kepada kelompok pendukungnya. Di mana seluruhnya bercampur dengan sifat dan rasa tidak pernah puas atau serakah manusia.

Dari kasus-kasus atau fenomena yang berkaitan dengan modus praktik jual-beli, rekrutmen dan promosi untuk mendapatkan jabatan tersebut. Bisa saja terbuka peluang secara tidak langsung dan terjadi replikasi modus yang sama di lingkungan BUMN. Apalagi sudah menjadi rahasia umum dan sebuah kritik bagi BUMN, meski dikelola oleh para profesional, tetap saja ada campur tangan pemerintah yang direpresentasikan oleh kelompok tertentu (partai politik) yang sedang berkuasa. Padahal secara prinsip, para penyelenggara negara (seluruh level jabatan) yang berada pada instansi publik, di mana saja mereka bertugas termasuk BUMN, seharusnya tetap bertanggung jawab kepada publik dan tidak boleh takluk karena godaan dan dorongan yang berasal dari faktor tekanan semata.

\section{Gratifikasi yang Memanfaatkan Celah Sebagai Faktor Kesempatan}

Gratifikasi memang memiliki posisi yang dilematis dan abu-abu. Sebab posisinya berhimpit antara zona putih sebagai perilaku yang berkesesuaian dan zona hitam sebagai perilaku kriminal (Samociuk \& Iyer, 2012). Dalam aktivitas bisnis, gratifikasi sering kali dianggap normal sebagai hal yang biasa dilakukan kepada relasi bisnis untuk menjaga hubungan baik. Bentuknya berbagai macam (barang/jasa), melalui media apa saja, dan bisa diberikan di mana-pun serta kapan-pun.

Berawal dari sebuah kelaziman, bahkan beberapa berkedok ramah-tamah atau sebuah tanda terima kasih sampai akhirnya menjadi kebiasaan. Sehingga banyak sekali yang luput untuk mengatur batasan yang ketat bagi aktivitas seperti ini karena dianggap bagian 
dari adat dan budaya setempat di mana mereka melakukan bisnis. Padahal jika tidak diatur atau dikelola, membuat gratifikasi bisa bersembunyi dibalik kewajaran, mengakali sistem yang kemudian masuk sebagai faktor kesempatan.

Faktor kesempatan datang biasanya disebabkan karena kelemahan atau terjadinya in-efektivitas dari sebuah sistem tata kelola pengendalian (internal dan risiko) pada organisasi. Termasuk yang melekat pada faktor ini adalah tidak adanya sanksi/hukuman yang membuat jera pelakunya. Menurut (Schuchter \& Levi, 2016) kalau faktor ini akan terbuka lebar manakala sebuah organisasi kurang melakukan pantauan, tidak melakukan audit reguler, dan tidak memeriksa langkah apa saja yang harus diperbaiki dalam sebuah celah-celah keamanan. Padahal bagi seseorang yang berkomitmen melakukan gratifikasi maupun bentuk kecurangan lain. Pasti telah memahami sebuah kelemahan dan akan memanfaatkan titik celah yang ada pada sebuah sistem pengendalian/kontrol internal organisasinya (Mansor, 2015).

Berkaitan dengan sebuah sistem, yaitu berupa pengendalian gratifikasi yang ada di BUMN. Saat ini ternyata dari sekian banyaknya BUMN dan juga termasuk BUMD di Indonesia, baru hanya $44,5 \%$ atau 65 perusahaan saja yang memiliki program implementasi pengendalian gratifikasi dalam tata kelolanya (KPK, 2018). Sangat sedikit dibandingkan jumlah BUMN yang mencapai 142 instansi dan ribuan BUMD yang tersebar di seluruh Indonesia. Meski adanya peraturan Menteri BUMN 01/MBU/2011 yang mewajibkan pelaksanaan tata Kelola perusahaan yang baik (good corporate governance) dan melakukan program "BUMN Bersih".

Faktor kesempatan lainnya juga muncul karena lemahnya pengawasan internal dan banyaknya pengawas di BUMN yang melakukan rangkap jabatan, yang akhirnya menjadi celah bagi para pejabatnya untuk korupsi. Akhirnya kini telah menjadi rahasia umum kalau para komisaris yang bertugas sebagai pengawas BUMN dipilih dengan dasar kepentingan politik dan tanpa mempertimbangkan kompetensi (Kompas.id, 2019). Besarnya celah kelemahan sebuah sistem pengawasan dan pengendalian tersebut. Hasilnya bisa kita tengok seperti kasus yang kini sedang menyeret direksi di PT Angkasa Pura II, PT Garuda Indonesia, PT Pelindo II, PT PAL Indonesia dan PT Jasindo (Laluhu, 2019). Apalagi ditambah muncul sebuah kondisi di mana suap, sebagai tindakan yang berkaitan erat dengan gratifikasi, di lingkungan swasta belum di atur. Seperti terjadi pada kasus yang menjerat Direktur Utama Perum Perikanan Indonesia dan PT Navy Asra Sejahtera (Kompas.id, 2019). Tentu akan memberi lebih banyak lagi celah sebagai faktor kesempatan sebagai momentum kesuburan dan potensi bagi tindak korupsi dalam sebuah relasi bisnis antara kedua belah pihak.

Beberapa contoh pemberian gratifikasi lainnya adalah penerimaan dan pemberian dalam bentuk bermodus parsel atau tunjangan hari raya (THR) di saat momen idulfitri atau 
Irvan S. Iskandar \& Teguh Kurniawan | Gratifikasi di Badan Usaha Milik Negara Berdasarkan Motif...

acara keagamaan lainnya (Tirto.id, 2019). Para penyelenggara negara di BUMN hingga para aparatur sipil negara, sebagai penerima, biasanya jadi sasaran oleh mereka yang berperan sebagai rekan bisnisnya. Para pemberi gratifikasi memanfaatkan celah pada momen hari raya keagamaan sebagai perilaku yang berlaku umum pada masyarakat untuk menanam sebuah jasa. Maka dari itu, untuk menghindari jerat pidananya, tidak ada pilihan lain bagi para penyelenggara negara untuk berani menolak atau melaporkannya kepada Komisi Pemberantasan Korupsi maksimal 30 hari setelah menerimanya.

\section{Menetralkan Rasa Bersalah Menerima Gratifikasi Sebagai Faktor Rasionalisasi}

Faktor rasionalisasi merupakan sebuah justifikasi individu terhadap sebuah perilaku yang tergolong tidak etis (Sandhu, 2016). Proses justifikasi memerlukan waktu yang melibatkan akal, persepsi beserta pemahaman seseorang mengenai perilakunya. Sehingga seseorang sebagai pelaku bisa memutuskan untuk mau dan bisa menerima, mempertimbangkan, dan dapat menetralkan rasa bersalahnya meski melakukan tindakan yang salah. Begitu pula apa yang terjadi pada diri seseorang yang menetralkan rasa bersalahnya ketika menerima sebuah gratifikasi. Anand, Ashforth, \& Joshi (2004) dan Gault (2017) menjabarkan macam-macam bentuk rasionalisasi yang mungkin salah satu atau lebih memenuhi pertimbangan seseorang dalam melakukan tindakan kecurangan, sebagai berikut:

1. Denial of responsibility; Seseorang merasa kalau ini merupakan pilihan yang tidak bisa dihindarkan dan harus diterima/diikuti karena sistem yang terlanjur berjalan. Semua orang dilingkungan menerima gratifikasi, maka mau tidak mau seseorang juga ikut menerimanya

2. Denial of injury; Seseorang tidak merasakan potensi yang berbahaya dari tindakannya. Semua akan berjalan baik-baik saja. Gratifikasi dianggapnya sebagai hadiah dan yang ada malah sebuah keuntungan yang bisa dinikmati.

3. Denial of victim; Seseorang tidak merasakan kerugian bagi pihak mana-pun karena tindakan ini dirasa sama-sama menguntungkan kedua belah pihak. Ini karena keduanya merasa saling bersahabat dan relasi bisa terus terjaga untuk di masa yang akan datang.

4. Social weighting; Seseorang telah melakukan perbandingan secara sosial secara selektif saat sebelum maupun sesudah melakukan tindakannya. Membandingkan perilakunya dengan orang lain yang lebih parah dari tindakannya.

5. Appeal to higher loyalties; Seseorang melakukan tindakan karena sebagai upaya mengikuti standar nilai dan loyalitas yang lebih tinggi di atasnya. Ini menyangkut reputasi dan anggapan dirinya di mata masyarakat atau rekan kerjanya. 
6. Balancing the ledger; Seseorang merasa kalau hal ini adalah pantas untuk dinikmati karena ada hasil kerja dan upaya keras mereka.

Ada lagi tiga bentuk proses rasionalisasi yang dijabarkan oleh Gault (2017) serta Anand et al. (2004) sebagai bentuk pemahaman secara logis atas normalisasi tindakan korupsi. Termasuk Jika dikaitkan dalam konteks gratifikasi, yaitu sebagai berikut; Pertama, adalah proses kooptasi dengan cara berbagi manfaat, minat dan risiko pada tindakan korupsi yang dilakukan secara bersama (kelompok) sehingga hilang ambiguitas seseorang karena tidak lagi bisa membedakan mana yang benar dan mana yang salah; Kedua, inkremental atau tindakan awalnya diperkenalkan kepada seseorang secara bertahap atau menerima dari yang kecil, sampai akhirnya melakukan tindakan yang lebih besar dan sangat korup; Ketiga, adalah kompromi sebagai sikap berdamai dengan lingkungan organisasinya dan berharap konflik bisa segera diatasi karena aturan/standar/norma dalam organisasi dianggapnya kini menjadi lebih fleksibel. Pada akhirnya, meski gratifikasi adalah perbuatan yang salah dan jelas melawan hukum. individu atau pelaku tetap saja melakukannya dengan terus mencari pembenaran dan tidak merasakan sebuah kesalahan.

Contoh kasus gratifikasi yang terjadi karena faktor rasionalisasi bisa dilihat pada kasus yang menjerat salah satu mantan direksi PT Garuda Indonesia (Persero) Tbk. Alasan pertemanan dan loyalitas, sistem yang harus diikuti, dan tidak adanya korban yang merasa dirugikan menjadi justifikasi perbuatan tersangka. Dalam pengakuan dan pembelaannya tersangka merasa tidak merugikan keuangan negara atau perusahaan, mengakui telah menerima sejumlah uang karena menganggap pemberian tersebut adalah berasal dari temannya, dan merasa tidak enak jika menolaknya (Kompas.com, 2020). Tidak berhenti disitu, keterangan dari saksi di persidangan kemudian semakin memperkuat kesalahannya. Saksi mengatakan bahwa beliau menganggap sistem whistle blowing akan membahayakan, dan gratifikasi merupakan hal yang wajar dalam bisnis (Natalia, 2020). Sehingga ada beberapa alasan yang melatarbelakangi rasionalisasi dari kasus gratifikasinya, yang kemudian berujung menjadi suap, dan bisa meyakinkan penegak hukum membuktikan kesalahannya dengan vonis delapan tahun penjara beserta denda (Nuralam, 2020).

\section{Menerima Gratifikasi dengan Memanfaatkan Jabatan Sebagai Faktor Kapabilitas}

Faktor kapabilitas diperkenalkan oleh Wolfe \& Hermanson (2004) pada teori motif kecurangan berlian (fraud diamond theory). Kapabilitas merupakan kemampuan yang dimiliki seseorang berkaitan dengan sifat, jabatan, posisi atau tugas yang sedang melekat pada dirinya. Potensi pelanggaran bisa datang ketika seorang pelaku merasa memiliki kewenangan dan bisa melakukan apa saja berkat kedudukan dan kekuasaan atau 
Irvan S. Iskandar \& Teguh Kurniawan | Gratifikasi di Badan Usaha Milik Negara Berdasarkan Motif...

jabatannya. Terlebih jika ini disadari oleh mereka untuk mengubah, menghindari sistem/peraturan yang ketat, dan terdukung bertemu dengan faktor-faktor lainnya.

Seperti dalam hasil penelitian dari Rustiarini, Sutrisno, Nurkholis, \& Andayani (2019) mengenai kasus kecurangan dalam pengadaan barang/jasa di sektor publik. Hasil penelitiannya menunjukkan kalau faktor tekanan dan kesempatan pada seseorang dengan kapabilitas memberikan rasionalisasi untuk melakukan tindakan kecurangan. Dalam hal ini mereka yang mempunyai kapabilitas dan mengetahui ada sebuah kekurangan dalam sistem pengendalian internal organisasinya, atau bertemu dengan kesempatan, secara tidak sadar berpotensi akan melakukan berbagai jenis tindakan kecurangan dengan tenang dan tanpa adanya rasa takut atau bersalah.

Wolfe \& Hermanson (2004) membagi enam elemen penting yang melekat pada faktor kapabilitas, yaitu; (1) Posisi atau jabatan yang sedang dilakoni oleh seseorang, lewat hal ini individu merasa memiliki kemampuan, kekuasaan dan kewenangan untuk melakukan tindakan dari yang etis sampai tidak etis; (2) Kecerdasan, individu yang melakukan tindakan korupsi merupakan pribadi yang cukup cerdas, kreatif, berpengetahuan dan berpengalaman yang saling berkombinasi untuk mengakali sebuah sistem; (3) Percaya diri atau ego sebagai pengontrol situasi sekaligus bentuk kekuatan dan superioritas dalam diri; (4) Memiliki kemampuan merayu/memaksa yang baik atau artinya punya daya persuasi yang tinggi; (5) Efektif dalam berbohong, artinya individu tersebut sangat lihai dalam menyembunyikan sesuatu; (6) Tahan terhadap stres, sebagaimana orang cerdas dan memiliki jabatan yang tinggi, seseorang tentu memiliki daya tahan terhadap tekanan dan bisa tetap terlihat tenang.

Enam elemen pada faktor kapabilitas ini terdukung dari bukti banyaknya kasuskasus yang menguatkannya. Dari banyaknya pelaku korupsi, termasuk kasus gratifikasi dan suap, yang berhasil diproses oleh penegak hukum. Adalah mereka yang menjabat sebagai kepala daerah, pejabat negeri di jabatan sipil dan yang paling utama terkait dengan tulisan ini adalah para pimpinan di perusahaan milik negara.

Dapat dilihat dari sederet daftar pelanggaran etik yang melibatkan para petinggi BUMN, seperti di antaranya: Direksi PT. PAL (Direktur utama, Kepala divisi Perbendaharaan, dan Direktur Keuangan), Direksi PT. Jasindo (Direktur Utama), Direksi PT. Krakatau Steel (Direktur Teknologi dan Produksi), Direksi PT. Perusahaan Listrik Negara (Direktur Utama), Direksi PT. Angkasa Pura II (Direktur Keuangan), Direksi Perum Perikanan Indonesia (Direktur Keuanngan dan Direktur Operasional), Direksi PT. INTI (Direktur Utama) pada era Menteri BUMN 2014-2019 (Cnbcindonesia.com, 2019). Mereka yang tertangkap adalah seorang pejabat tinggi di instansinya, berpendidikan tinggi, memiliki kemampuan persuasi, dan tentu tahan terhadap stres berkaitan dengan tanggung jawab pekerjaan dan posisinya. Mereka semua adalah pembuat keputusan atau pemimpin yang memiliki jabatan pada 
perusahaan negara dengan bisnis strategis dan beberapa perusahaannya bersinggungan dengan pelayanan publik. Selayaknya pejabat tinggi penyelenggara negara yang duduk di instansi eksekutif, legislatif dan yudikatif. Setidaknya sepanjang tahun 2014-2018, ada 56 orang dari BUMN, termasuk pimpinan di dalamnya yang ditangkap karena kasus suap (Pramasta, 2019).

Mengenai faktor kapabilitas, harusnya bisa di ingat. Sebagaimana pasal-pasal yang ada pada UU No.31/1999 jo. UU No. 20/2001, sebetulnya sudah mengatur siapa saja dan dengan jabatan apa saja yang seharusnya wajib patuh melaporkan atas penerimaan gratifikasi. Termasuk pimpinan dan karyawan BUMN dan BUMD telah tercantum dalam peraturan tersebut. Dengan mengelola, mengatur dan melaporkan gratifikasi, maka hal ini berguna untuk melepas konflik kepentingan dan mengantisipasi kalau posisi mereka dapat berpotensi menjadi sasaran dari kejahatan korupsi. Itu semua tidak lain karena jabatan yang melekat dan pekerjaan mereka (karyawan dan pimpinan BUMN) berhubungan dengan fasilitas atau uang negara di dalamnya baik secara langsung maupun tidak langsung. Dikhawatirkan juga karena mereka, pimpinan dan pegawai BUMN/BUMD, bisa ikut terpengaruh dan melakukan bentuk tindakan kecurangan lainnya yang lebih destruktif atau koruptif.

Badan usaha milik negara di Indonesia sudah saatnya diselamatkan dengan pemimpin bisnis dengan etika kepemimpinan yang menjunjung dan memainkan peran penting dalam membina serta mempertahankan nilai integritas organisasi (van Eeden Jones \& Lasthuizen, 2018). Oleh sebab, pemimpin bisnis milik negara adalah role model bagi para anggota (karyawan) serta sebagai cerminan organisasinya. Kemauan politik pimpinan sebagai pejabat yang berwenang di BUMN memberikan kepastian dan sangat menentukan sejauh mana organisasinya bisa menerapkan sistem antikorupsi. Supaya bisa memberikan salah satu wujud nyata yang sebenarnya dalam sebuah perolehan nilai indeks tata kelola perusahaan yang baik (good corporate governance) dan berbisnis dengan integritas. Untuk mencapai apa yang semula dicita-citakan dan menjadi tujuan dengan adanya perusahaan milik negara.

\section{Penutup}

Melalui uraian artikel ini, selain menjawab faktor apa saja yang membuat masih terjadinya penerimaan terhadap gratifikasi oleh para penyelenggara negara. Memberikan sebuah kewaspadaan dan atensi bersama mengenai bahaya yang bisa timbul sesuai dengan kondisi individu yang berpengaruh atas citra pengelolaan organisasi bisnis di BUMN. Di mana faktor-faktor yang melekat pada individu tersebut memainkan peranan vital yang menuntunnya dalam berlaku, menilai/menimbang salah atau benar, menjaga integritas, dan bertanggung jawab atas perbuatannya secara pribadi. Pada akhirnya, dapat menjadi 
Irvan S. Iskandar \& Teguh Kurniawan | Gratifikasi di Badan Usaha Milik Negara Berdasarkan Motif...

catatan penting berkaitan dengan cara pengawasan internal dan pengelolaan gratifikasi di instansi mereka, secara organisasi, yang ternyata masih dianggap rentan atau lemah oleh Komisi Pemberantasan Korupsi dan publik yang dijelaskan dalam Direktorat Penelitian dan Pengembangan KPK Tahun 2011).

Dari laporan gratifikasi yang terkumpul dan beberapa kasus yang berujung menjadi tindak pidana korupsi dan pidana suap di lingkungan BUMN. Gratifikasi sudah tentu merupakan sebuah tindakan yang berkonsekuensi. Dengan menempatkannya sebagai salah satu bentuk perbuatan kecurangan. Tidak ada jalan lain bagi korporasi milik negara supaya terus berusaha patuh mengendalikan dan memperkuat tata kelola organisasinya menjadi lebih yang baik. Jika penyelenggara atau pejabat negara di BUMN masih meremehkan dan tetap melanggarnya, tentu akan ada konsekuensi hukum yang menunggu dan dapat menjerat pelaku atas perbuatannya. Ada baiknya pada BUMN membuat peraturan (bagi yang belum memiliki), atau menjalankan standar prosedur operasional (bagi yang sudah memiliki) mengenai pengelolaan gratifikasi pada organisasinya secara lebih bersungguhsungguh. Sebagai upaya serius pencegahan tindakan korupsi yang lebih masif dan ikut mewujudkan kepatuhan terhadap hukum. Supaya tidak menambah lagi daftar panjang kasus korupsi serupa, mengembalikan kepercayaan publik, dan berakhir pada membaiknya pengelolaan bisnis vital yang dimiliki negara

\section{Ucapan Terima Kasih}

Terima kasih kepada Dion (Komisi Pemberantasan Korupsi, bidang gratifikasi), Ferdian Yazid (Transparency International Indonesia) dan Bambang Widjojanto atas diskusi dan masukannya kepada penulis.

\section{Pendanaan}

Penulis tidak menerima bantuan pembiayaan untuk penelitian, kepenulisan (authorship) dan publikasi dari pihak mana pun.

\section{Daftar Pustaka}

Albrecht, W. S., Albrecht, C. O., Albrecht, C. C., \& Zimbelman, M. F. (2011). Fraud Examination. Cengage Learning.

Anand, V., Ashforth, B. E., \& Joshi, M. (2004). Business as Usual: The Acceptance and Perpetuation of Corruption in Organizations. Academy of Management Perspectives, 18(2), 39-53.

Anita, B. (2017). OECD Guidelines on Corporate Governance of State-Owned Enterprises from Hungarian State-Owned Enterprises' Point of View. Pro Publico Bono-Magyar Közigazgatás, 5(Special Edition 1), 6-25.

Argandona, A. (2005). Corruption and Companies: The Use of Facilitating Payments. Journal 
of Business Ethics, 60(3), 251-264.

Cnbcindonesia.com. (2019). Deretan Direksi BUMN yang Terciduk KPK di Bawah Pimpinan Rini. Retrieved from https://www.cnbcindonesia.com/news/20190801123255-489099/deretan-direksi-bumn-yang-terciduk-kpk-di-bawah-pimpinan-rini

Cressey, D. R. (1950). The criminal Violation of Financial Trust. American Sociological Review, 15(6), 738-743.

Creswell, J. W. (2014). Research Design: Pendekatan Kualitatif, Kuantitatif, dan Mixed. Yogyakarta: Pustaka Pelajar.

Dellaportas, S. (2013). Conversations With Inmate Accountants: Motivation, Opportunity and the Fraud Triangle. Accounting Fórum, 37(1), 29-39.

Direktorat Penelitian dan Pengembangan KPK. (2011). Laporan Hasil Studi Prakarsa Anti Korupsi pada Badan Usaha Milik Negara (BUMN) Tahun 2011. Jakarta: Komisi Pemberantasan Korupsi.

Dorminey, J., Fleming, A. S., Kranacher, M.-J., \& Riley Jr, R. A. (2012). The Evolution of Fraud Theory. Issues in Accounting Education, 27(2), 555-579.

Fathonah, E. (2017). Analisis Pelaksanaan Upaya Pengendalian Gratifikasi Dalam Rangka Reformasi Birokrasi Di Kementerian Pendayagunaan Aparatur Negara Dan Reformasi Birokrasi. Universitas Indonesia, Depok.

Gabrielian, V., Yang, K., \& Spice, S. (2018). Qualitative Research Methods. New York: CRC Press.

Gault, D. A. (2017). Corruption as an Organizational Process: Understanding the Logic of the Denormalization of Corruption. Contaduría y Administración, 62(3), 827-842.

Huat, C. B. (2016). State-Owned Enterprises, State Capitalism and Social Distribution in Singapore. The Pacific Review, 29(4), 499-521.

Hutauruk, Dina, M. (2018). Tahun ini bakal naik, simak besaran gaji dan tunjangan direksi Bank BUMN tahun 2018. Retrieved from https://keuangan.kontan.co.id/news/tahunini-bakal-naik-simak-besaran-gaji-dan-tunjangan-direksi-bank-bumn-tahun-2018

Jessica. (2015). Tinjauan Yuridis Batasan Nilai Atas Gratifikasi dan Pelaksanaan Lelang Pada Barang Hasil Gratifikasi. Universitas Indonesia, Depok.

Kankaanpää, J., Oulasvirta, L., \& Wacker, J. (2014). Steering and Monitoring Model of StateOwned Enterprises. International Journal of Public Administration, 37(7), 409-423.

Kompas.id. (2019). Sistem Antikorupsi di BUMN Belum Berjalan Optimal. Retrieved from https://kompas.id/baca/utama/2019/08/02/sistem-antikorupsi-di-bumn-belumberjalan-optimal/

Kompas.com (2020). Saksi Ungkap Emirsyah Satar Pernah Bilang Gratifikasi Hal Wajar. Retrieved from https://nasional.kompas.com/read/2020/02/13/16281231/saksiungkap-emirsyah-satar-pernah-bilang-gratifikasi-hal-wajar?page=all

Korupsi, K. P. (2018). Laporan Tahunan 2018. Jakarta: Komisi Pemberantasan Korupsi. Laluhu, S. (2019). Penerimaan Suap dan Gratifikasi, Tradisi Berujung Pidana. Retrieved from 
Irvan S. Iskandar \& Teguh Kurniawan | Gratifikasi di Badan Usaha Milik Negara Berdasarkan Motif...

https://kumparan.com/sabir-laluhu/penerimaan-suap-dan-gratifikasi-tradisiberujung-pidana-1rFSeWt6FcN

Mansor, N. (2015). Fraud Triangle Theory and Fraud Diamond Theory. Understanding the Convergent and Divergent for Future Research. International Journal of Academic Research in Accounting, Finance and Management Science, 1, 38-45.

Manual, A. F. E. (2011). International Edition. Association of Certified Fraud Examiners.

Mapuasari, S. A., \& Mahmudah, H. (2018). Korupsi Berjamaah: Konsensus Sosial atas Gratifikasi dan Suap. Integritas, 4(2), 159-176. https://doi.org/10.32697/integritas. v4i2.279

Natalia, D. L. (2020). Emirsyah Satar Sebut Terima Gratifikasi Sebagai Sebuah Kewajaran. Retrieved from https://www.antaranews.com/berita/1295026/emirsyah-satar-sebutterima-gratifikasi-sebagai-suatu-kewajaran

Nuralam, C. Y. (2020). Emirsyah Satar Divonis 8 tahun penjara. Retrieved from https:// www.medcom.id/nasional/hukum/nN90yLeK-emirsyah-satar-divonis-8-tahun penjara?utm_source=nasional\&utm_medium=terkait\&utm_campaign=detail_deskto $p$

Pramasta, D. B. (2019). Ketika Dinasti Politik Semakin Menguat... Retrieved February 2, 2020, from https://www.kompas.com/tren/read/2019/10/06/073000765/ketikadinasti-politik-semakin-menguat-?page=all

Putninšs, T. J. (2015). Economics of State-Owned Enterprises. International Journal of Public Administration, 38(11), 815-832.

Rustiarini, N. W., Sutrisno, T., Nurkholis, N., \& Andayani, W. (2019). Why People Commit Public Procurement Fraud? The Fraud Diamond View. Journal of Public Procurement.

Samociuk, M. M., \& lyer, M. N. (2012). Fraud and Corruption: Prevention and Detection. Gower Publishing, Ltd.

Sandhu, N. (2016). Behavioural Red Flags of Fraud-A Qualitative Assessment. Journal of Human Values, 22(3), 221-237.

Santoso, T. (2011). Menguak relevansi kasus gratifikasi di indonesia. Journal of Financial Crime, 15(4), 223.

Satyoadi, A. R. (2015). Analisis Efektivitas Sistem Pengendalian Intern Pemerintah Untuk Pencegahan Korupsi Berupa Gratifikasi: Studi Kasus Pemerintah Kota Tangerang 2009 - 2013. Universitas Indonesia, Depok.

Schuchter, A., \& Levi, M. (2016). The Fraud Triangle Revisited. Security Journal, 29(2), 107121.

Tirto.id. (2019). KPK Terkendala Pembuktian Gratifikasi Seks. Retrieved January 31, 2019, from https://tirto.id/kpk-terkendala-pembuktian-gratifikasi-seks-dfwm

Tirto.id. (2019). KPK Terima 94 Laporan Gratifikasi terkait Hari Raya Idulfitri. Retrieved June 11, 2019, from https://tirto.id/kpk-terima-94-laporan-gratifikasi-terkait-hari-rayaidulfitri-ecc6 
van Eeden Jones, I., \& Lasthuizen, K. (2018). Building Public Sector Integrity in Indonesia: The Role and Challenges of Ethical Leadership. Asia Pacific Journal of Public Administration, 40(3), 175-185.

Wolfe, D. T., \& Hermanson, D. R. (2004). The fraud diamond: Considering the Four Elements of Fraud.

Yeung, R. L. K. (2005). Public Enterprise Governance: KCR Corporation and Its Governance Controversies. Public Management Review, 7(4), 565-587.

Zhao, C., \& Zhang, Y. (2015). Several Major Issues on Deepening State-Owned Enterprises Reform. China Economic Journal, 8(2), 143-157.

\section{Tentang Penulis}

Irvan Sebastian Iskandar adalah mahasiswa Magister Ilmu Administrasi, Universitas Indonesia. Penulis memiliki peminatan kajian seputar administrasi dan kebijakan publik.

Teguh Kurniawan adalah dosen Fakultas Ilmu Administrasi, Universitas Indonesia. Penulis menggeluti bidang riset tentang tata kelola pemerintahan, korupsi, dan kebijakan publik. 